\title{
QUEEN'S
UNIVERSITY
BELFAST
}

\section{Updating Addison: Culture, Appropriation and The Connoisseur}

Regan, S. (2015). Updating Addison: Culture, Appropriation and The Connoisseur. Forum for Modern Language Studies, 51(1), 1-14. https://doi.org/10.1093/fmls/cqu064

Published in:

Forum for Modern Language Studies

Document Version:

Peer reviewed version

Queen's University Belfast - Research Portal:

Link to publication record in Queen's University Belfast Research Portal

Publisher rights

(c) 2014 The Author

This is a pre-copyedited, author-produced PDF of an article accepted for publication in Forum for Modern Language Studies following peer review. The version of record Regan, S 2015, 'Updating Addison: Culture, Appropriation and The Connoisseur' Forum for Modern Language Studies, vol 51, no. 1, pp. 1-14., is available online at: http://dx.doi.org/10.1093/fmls/cqu064

\section{General rights}

Copyright for the publications made accessible via the Queen's University Belfast Research Portal is retained by the author(s) and / or other copyright owners and it is a condition of accessing these publications that users recognise and abide by the legal requirements associated with these rights.

Take down policy

The Research Portal is Queen's institutional repository that provides access to Queen's research output. Every effort has been made to ensure that content in the Research Portal does not infringe any person's rights, or applicable UK laws. If you discover content in the Research Portal that you believe breaches copyright or violates any law, please contact openaccess@qub.ac.uk. 


\section{Updating Addison: Culture, Appropriation, and The Connoisseur}

These are interesting times for the eighteenth-century periodical, to judge by treatments of the genre in recent critical literature. For Jason Solinger in Becoming the Gentleman (2012), mid-century periodicals such as The Connoisseur and The World were crucial to a historical process whereby printed texts, rather than lived experience, became the touchstones and conduit of gentlemanly 'knowledge of the world' ${ }^{1}$ By contrast, Simon Dickie, in Cruelty and Laughter (2011), jibes at the 'periodical moralizing' of the age and dispatches such works (including The Spectator and The Connoisseur) in two brief paragraphs, in part for their indulgent treatment of aristocratic vice. ${ }^{2}$ In a more sustained discussion, Urban Enlightenment and the Eighteenth-Century Periodical Essay (2014), Richard Squibbs has addressed the 'failure of the genre to create prominent and sustainable literary publics' and explored how, from mid-century, periodical writers began to model a virtual 'counterpublic' to the faltering public sphere - one consequence of which was the 'conspicuously ironic turn' within the genre at this time. ${ }^{3}$ Meanwhile, in a 2011 overview of the ‘ripening’ field of eighteenth-century periodical studies, Manushag Powell notes that The Connoisseur, for example, is 'highly important' to our understanding of the period but that, like many such works (including its contemporary rival, The World), it lacks any 'modern edited edition'. ${ }^{4}$ What emerges 
from these recent studies, then, is a rather mixed picture: of a genre that was central to the culture yet stood in problematic relation to it (and is now fairly obscure), that commented on important issues of the day yet was unable to speak to its readers directly, and that was involved in a project of social reform yet, for that very reason, comes under suspicion - for some modern readers - as a fusty agent of moralizing cant.

This fraught assessment of the eighteenth-century periodical partly reflects the difficulties that a range of publications during this period encountered when positioning themselves in relation to an increasingly prominent cultural sphere of politeness, entertainment, and sociable commerce. At the upper end of the social spectrum, this was the world of the 'beau monde', a term that, as Hannah Grieg has shown, captured 'the emergence of an urban, primarily metropolitan, "world of fashion”', the denizens of which comprised an 'elite within an elite' within London society and the nation itself. ${ }^{5}$ Among the journals that displayed this fashionable milieu to the reading public, one of the most significant was The Connoisseur. Founded and mostly written by Bonnell Thornton and George Colman, The Connoisseur first appeared in 140 weekly numbers (published on Thursdays) between 31 January 1754 and 30 September $1756 .{ }^{6}$ As indicated by its title, the Connoisseur papers were primarily concerned with matters of taste. In this respect, the papers were timely, catching the mood (and indeed the taste) of the times. As Lance Bertelsen notes, taste - a 'code word for knowing how and what to consume' - was becoming something of a 'vogue' at this time. ${ }^{7}$ For contemporary commentators, this voguish discourse about taste involved not just consuming culture but, also, filtering culture and fashioning it to a desirable social image. Taste, as John Brewer puts it, was principally a matter of 'how culture was appreciated rather than how it was made'. ${ }^{8}$ For writers such as Colman and Thornton, this notion of taste as appreciation had a double import. For, while The Connoisseur sought to educate its 
readers' tastes, it was also involved in its own practice of taste: appreciating culture in tasteful ways for this readership, while largely avoiding practices that lay beyond the borders of taste, such as participation in the fractious 'paper wars' that punctuated literary culture at this time. ${ }^{9}$

In conducting its weekly survey of the realms of taste, The Connoisseur was markedly self-conscious about the generic inheritance of its undertaking. In particular, Colman and Thornton sought to emulate The Spectator, and took much from their model: its use of a periodical persona (or eidolon); its focus on matters of taste, urban behaviour and style; the essay format itself. Through its various allusions to and invocations of both The Spectator and The Tatler, The Connoisseur thus contributed to the canonisation and cultural renewal of Addison and his journals during the second half of the eighteenth century. ${ }^{10}$ At the same time, by adopting their predecessors' form and approach, Colman and Thornton were also attempting to appropriate the cultural space that had been occupied by Addison and Steele’s essays, forty years earlier. In this way, The Connoisseur offers a revealing insight into processes of appropriation that took place within the perimeters of the eighteenth century itself. Rather than adapting the literature of different nations and eras (as with the mock-epic recasting of classical epic, or the novelistic reworking of Don Quixote), Colman and Thornton were grappling with a recent, native production: a precursor text that might already appear to speak to the very society, and many of the same concerns, they themselves were seeking to address. In part, this engagementdeavour would see the new journal replaying The Spectator's own troubled relationship to fashion and the forms of civility. ${ }^{11}$ Yet emulating The Spectator could never be just a matter of applying its principles to a later cultural context, or of restaging its uncertainties about the modes of the moment. Adopting the Addisonian model also involved updating Addison. In essaying contemporary taste, The 
Connoisseur would thus find itself mediating between genre and history: between the treatment of fashionable modes in its most important precursor journal and the new forms, and enlarged scope, of fashionable culture at its own mid-century moment.

The lifestyle of the fashionable was at the heart of the weekly essays that comprised Thornton and Colman's journal during the middle years of the 1750s. From the perspective of its urbane person, 'Mr Town', The Connoisseur analysed the regions of taste with whimsical humour and a keen eye for the ridiculous in dress, behaviour, and diversion, paying particular attention to the life of the capital, 'this grand mart of pleasure’ (in Mr Town’s designation). ${ }^{12}$ For Lance Bertelsen, in his study of the 'Nonsense Club' (which numbered Thornton and Colman among its members), the 'majority' of the Connoisseur essays were concerned with 'the conventional vices and foibles of London society' - from female boldness to effeminate male manners, the use of make-up to the taking of snuff. ${ }^{13}$ In the view of one of Mr Town's many correspondents, this latter foible, snuff-taking, was both a 'filthy practice' and a 'national plague', and thus contrary to the character of a people - like the British - who 'pretend to politeness'. ${ }^{14}$ Such behaviour was perhaps only to be expected, though, in a nation that increasingly took its cultural and sartorial lead from France (the 'wardrobe of the world') and in which the very idea of a 'Fine Gentleman', 'in the modern sense of the word', was a man who 'whores, games, and wears a sword' - i.e., a fornicator, gambler, and dueller. ${ }^{15}$ Among these gentlemanly vices, gambling in particular proved a recurring anxiety, and was maligned to the extent that it departed from the normative model of the polite conversational gathering. In an imagined dialogue between a teatable and a card-table, for instance, the former criticises the 'refined pleasures' of the 
latter - a 'refined' pleasure being, from this viewpoint, an undesirable indulgence. ${ }^{16}$ If gambling was one of the 'conventional' vices or foibles of London society, though, the journal did not shy from pinpointing developments in the practice that seemed especially modish. Indeed, as Mr Town observed in May 1754, one of the most 'extraordinary' wagers to have taken hold in fashionable circles was 'pitting one man against another' (i.e., 'wagering which of the two will live longest'). Such a wager, it was implied, epitomised the smart set's substitution of dissipated amusement for the dutiful reserve appropriate to gentlemanly conduct. ${ }^{17}$

Beyond this sphere of frivolous town life, The Connoisseur also tackled the world of politics, particularly when elections were running in the country (most notably the Oxford election of 1754). Here again, though, it was new and fashionable forms of political engagement that were of especial concern. In a paper that addresses the current mania for war against France, 'all the polite world' are described as now 'hurrying to Portsmouth to see mock-fights, and be regaled on board the Admiral'. As Mr Town observes, politics had thus become 'once more fashionable'. ${ }^{18}$ As this focus on the modes à la mode suggests, it was in the workings of cultural politics, rather than the narrower field of party politics (or indeed international relations), that the interest of the journal truly lay. Instructive in this regard is the conceit of a 'Female Parliament' that was developed across a number of papers, including one (number 94) in which $\mathrm{Mr}$ Town describes his province as being to 'repell the daily inroads and encroachments made by vice and folly, and to guard the nation from an invasion of foreign fopperies and French fashions'. Among the measures proposed for consideration by this fictional female assembly were: 'A Bill for prohibiting the importation of French Milliners, Haircutters, and Mantua-makers. - A Bill for the exportation of French Cooks and French Valets de Chambres. - A Bill to restrain Ladies from wearing French Dresses. - And 
lastly, a Bill to restrain them from wearing French Faces'. ${ }^{19}$ If the imagining of such bills constituted a form of political patriotism, then this was patriotism under the sign of culture, in fanciful legislation against the frivolous Frenchification of British behaviour. (As these parodic bills against French fashions also indicate, the 'Female Parliament' is envisioned in the journal as a legislative body for policing women, rather than as a forum for women's exercise of new political rights).

While this anxiety about a French cultural invasion had patriotically commercial underpinnings (and also, perhaps, figured forth latent fears of a literal invasion from France), it is important to register how easily this Gallophobic rhetoric dovetailed with the journal's broader critique of the lifestyle of the fashionable. The perceived interests and attitudes of the leisured rank of metropolitan society are outlined more fully in a facetious list of the books held by a 'Polite Circulating Library', which appeared in a letter included in issue 24 of the journal. Among the titles contained in this mockcatalogue are: 'A Description of THE WORLD; with the Latitudes of Vaux-Hall, Ranelagh, the Theatres, the Opera-House, \&c. calculated for the Meridian of St. James's'; 'The whole Duty of Woman. Dispersed under the Articles of Visiting, Cards, Masquerades, Plays, Dress, \&c.'; ‘The Art of Dissembling. From the French’; a dissertation upon spas; and ‘The Traveller’s Guide, or Young Nobleman’s Vade Mecum: Containing an exact List of the most eminent Peruke Makers, Taylors, and Dancing-Masters, \&c. Being the Sum of a Gentleman's Experience during his Tour thro' France and Italy'. ${ }^{20}$ Here was the culture of the beau monde exposed to critical view. A narrow (and somewhat courtly) conception of the meaningful social milieu; the displacement of religious ‘duty’ by a whirl of diversions; a multiplication of fashionable watering-holes; an education that inhered in outward preening rather than inner improvement; and an infatuation with the social arts (and the national vices) of the 
French - such were the attributes of leisured society, as characterised by Mr Town and his correspondents in the pages of The Connoisseur.

Besides an occasional foray into the country (via the correspondence of ' $\mathrm{Mr}$ Village', Town's provincial other), it was the cultural habits of this highly circumscribed 'world', centred in London's fashionable west end, that Thornton and Colman’s journal laid out before its readers. Tested within its pages against an implied standard of good taste, the beau monde would usually emerge unfavourably, displayed in some of its most superficial attitudes. While Colman and Thornton may, as Solinger argues, have ‘explicitly identified the periodical's task with the transmission of knowledge of the world', this task was largely prosecuted (as Solinger also observes) through producing 'object lessons' of idling aristocrats who ‘squandered the time and leisure that their pedigree conferred on them'. ${ }^{21}$ This was something worse, perhaps, than merely holding up negative examples as implied incitements to better conduct. The lifestyle of the British metropolitan beau monde, the journal seemed to be saying, practically precluded the expression of either grace or gout.

Within this investigation into mid-century fashionable mores, The Connoisseur looked back self-consciously to its principal models, the early eighteenth-century essays of Addison and Steele. The new journal's indebtedness to its celebrated precursors is acknowledged as early as its second number, as Mr Town refers directly to 'my predecessor, the SPECTATOR'. ${ }^{22}$ In truth, the mildly well-informed reader would have registered this alignment from the very first issue, in which Mr Town surveys the London coffee-houses and their clienteles and, Mr Spectator-like, reveals both his chameleonic quality and his cultural ubiquity: 'I am a Scotchman at Forrester's, a 
Frenchman at Slaughter's, and at the Cocoa-Tree I am - an ENGLISHMAN [...]

Wherever the WORLD is, I am'. ${ }^{23}$ In myriad other ways, also, The Connoisseur signalled its indebtedness to Addison and Steele and its awareness of this indebtedness. Like the ploy of including correspondence from readers (real or otherwise), the essays that record the persona's dreams or reveries replicate a device that was used to significant effect in The Spectator. Among other topics, the Connoisseur papers contain dreams about dogs (no. 64, contributed by the anonymous ‘A.B.'), female poets (no. 69), marriage cakes (no. 95), and pawnbroking (no. 117). Notably, the first example of the device in The Connoisseur (issue 3) sees Mr Town dreaming of an ocean of ink, and of the 'EDDIES of CRITICISM'. ${ }^{24}$ The reflexive concern with print conveyed by such inky imaginings is continued into subsequent papers that address more directly the world of print culture and periodical publication. In a paper that considers the visual impression of the published page, for instance, Mr Town goes so far as to compare the appearance of his own journal with that of The Spectator; noting, with ostensible humility, that while the Spectator papers were initially unadorned with print decorations, they nevertheless possessed more substance than do his own weekly sheets. ${ }^{25} \mathrm{Mr}$ Town’s periodic reflections upon the progress and the reception of his lucubrations also mimic those of Mr Spectator, as when Mr Village writes in to the penultimate number, affirming the journal's popularity in the country and requesting that he not be killed off in the final issue, as Addison had killed off Sir Roger de Coverley in Spectator number 517 (23 October 1712). ${ }^{26}$ Not only their essays, in fact, but Addison and Steele themselves come in for discussion in The Connoisseur - as in a paper on drinking, in which Mr Town observes that, contrary to the norm, Addison and Steele were able to be 'witty and agreeable in their cups' (with Addison taking over whenever Steele became 'stupified' with wine). ${ }^{27}$ Via this network of debts and 
allusions, then, Addison and Steele acquired a significant presence within the pages of Colman and Thornton's periodical.

The claim to succession implied by this presence would soon be reinforced publicly by Oliver Goldsmith's review of The Connoisseur in the Monthly Review for May 1757, in which Mr Town is praised as 'the first Writer since Bickerstaff, who has been perfectly satyrical, yet perfectly good-natured'. ${ }^{28}$ Goldsmith's assessment of the journal's good-natured, Bickerstaffian satire was, we might suspect, likely to have been guided by the journal's own positioning of itself with regard to the periodical essays of Addison and Steele. Yet Goldsmith’s appraisal also obscures some important differences between The Connoisseur and its by-now-canonical models. Unlike Addison and Steele, Colman and Thornton were writing their essays in the shadow of illustrious forebears. As their insistent allusions to and echoes of The Spectator might suggest, a new periodical publication concerning the regions of taste risked labouring under an anxiety of essayistic influence. ${ }^{29}$ Indeed, far from being dead artefacts, mere echoes from the past, Addison and Steele’s periodical writings remained current models at this time. As Terence Bowers notes, over seventy editions and reprints of The Spectator were published during the eighteenth century - which, along with other abridgements and selected anthologies, made the periodical 'one of the most widely read texts of the century’ ${ }^{30}$ More broadly, as Lawrence Klein has argued, The Spectator was part of the century's cultural consciousness, a 'living text' as well as a revered one, and Addison himself 'a kind of cultural legislator' in the popular imagination. ${ }^{31}$ As a mid-eighteenthcentury reader might justifiably have asked therefore: did the Addisonian essay need updating? And could Colman and Thornton's efforts possibly equal Addison and Steele’s own performances? 
Colman and Thornton's awareness of these concerns is made clear at the beginning of the second volume of the collected (two-volume) edition of The Connoisseur, as Mr Town reflects upon his aims in the journal. Evoking the burden of the Spectatorial past, Town observes that a modern critic would tell a budding periodical writer that 'to set up a new paper is a vain attempt after the inimitable SPECTATORS'. ${ }^{32}$ As the Connoisseur's mouthpiece acknowledges, The Spectator would always be distinguished in the field of periodical-writing, as having led the way for all subsequent journals. The central issue here was that of priority as a condition of literary value. In the terms that Edward Young would popularise later in the decade (in a work, Conjectures on Original Composition (1759), that also sanctified Addison's moral character), Colman and Thornton were mere imitators of genius, rather than creators of something new. Literary successors, in this view, could never achieve priority either as originals or as the most important purveyors of their art. Later in the century, the priority of Addison and his journals would be ratified by Samuel Johnson, whose 'Life' of the author characterised The Spectator and The Tatler as the originators of middle-way reform (reforming both 'the savageness of neglect' and 'the impertinence of civility') and Addison himself as the pre-eminent writer of his kind: an author who, as 'a describer of life and manners [...] must be allowed to stand perhaps the first of the first rank’.33 From this vantage point, Colman and Thornton necessarily appeared belated, labouring over a weekly publication that would, perhaps could, only ever be a shadow of the original and leading product in its field.

If Colman and Thornton were willing to accept that their journal could never stand as an originating point in its kind, though, they were more combative on the question of whether they should be writing at all. Denying that all possible topics for essayistic treatment are 'already preoccupied', Mr Town contends rather that there will 
always be new topics on which to discourse - and, importantly, 'New objects for ridicule' ${ }^{34}$ The Spectator might still have been current in printed form, but culture had not stood still during the 40 years - 2 generations - since its contents were written. Nor were Colman and Thornton quite in the position of the author in Borges, who writes Don Quixote anew. ${ }^{35}$ In words that echoed Addison's 'Pleasures of the Imagination' papers, the essayists asserted their quest for 'new and uncommon' subjects of their own on which to write. Even in its Spectatorial allusions, The Connoisseur's application of the Addisonian model to a later cultural moment thus entailed a difference that was substantive as well as (merely) temporal. ${ }^{36}$

Notably, in this mid-journal stock-taking, Colman and Thornton also argued a distinction between their own satiric practice and that of their forebears. Rather than moralising in the manner of The Spectator, he claims, Mr Town has aimed at 'exposing vice and folly by painting the actors in their natural colours, without assuming the rigidness of a preacher, or the moroseness of a philosopher', so that he has 'oftener chose to undermine our fashionable excesses by secret sapping, than to storm them by open assaults'. Compared with The Spectator, The Connoisseur is presented here as less judgemental, less moralistic, and even gentler in its satiric conduct. Endeavouring to 'laugh people into a better behaviour', Mr Town thus proceeds according to the conviction that 'the sting of reproof is not less sharp for being concealed; and advice never comes with a better face, than when it comes with a laughing one'. ${ }^{37}$ For all the apparent assurance with which it articulates this departure from the Spectator's modus operandi, this account of its satiric method as a jovial yet concealed 'secret sapping' raises as many questions as it answers about quite where The Connoisseur stood in 
relation to the 'fashionable excesses' of the age. Consideration of this satiric selffashioning can move us towards a more particular sense of the process by which appropriating the Addisonian essay in new circumstances would lead to an updating of the Spectatorial model.

In illustration of its equivocal cultural positioning, we can consider the journal's treatment of the irreligion of the fashionable - specifically, their lack of church attendance - which is addressed in a number of its papers. In an early comment in issue number 9, Mr Town bluntly observes that 'nothing but another earthquake can ever fill the churches with people of quality’. Moving beyond this stark appraisal, later papers are more prone to construct ironies out of the very image of the beau monde at church. Noting that Sunday church-going is for many a 'mere matter of diversion', deriving from 'the same motives that they frequent other public places', for instance, essay 26 suggests precisely how the church could be viewed as meeting the criteria of a fashionable gathering-place, somewhere ‘to see and be seen' and to engage in 'bows, nods, curt'sies, and loud conversations' ${ }^{38}$ Conversely, a paper on the daily routine of people of quality, who follow the court-calendar , archly observes that the fashionable diary in effect reduces the saints to 'people whom nobody knows' and that Lent itself has now become a carnival-like season of 'diversion and jollity' among the 'Beau Monde' in the nation's capital. ${ }^{39}$ Yet if the double-edged ironies here might seem to sit easily within a satiric critique of fashionable irreligiosity, a more extensive comparison of churches with arenas for public sociability, in essay 106, begins to suggest greater leniency in Mr Town's position. In order to make it as fashionable to be seen at church 'as it was some time ago to meet at Ranelagh on a Sunday', Town argues, people of fashion must be allowed whilst there to 'curtesy, bow, nod, smile, ogle, whisper, or even bawl to one another'. In this manner, churches would come to resemble 'other public 
places of diversion'. For all its ironic playfulness, the journal's rationale for its satiric approach here is telling. Arguing that such fashionable amusements as masquerades and gambling can only be improved, not actually abolished, Mr Town contends that it is necessary to 'wean' people of fashion from their vices gradually - and that this reformation will only ever be partial. ${ }^{40}$ Here, then, is the variation that The Connoisseur turns on the Addisonian periodical. If Mr Spectator had engineered a satire that might heal while it wounded, what Mr Town proposes is rather to meet his satiric targets halfway - settling, in his own terms, for only partly undermining the 'excesses' of the fashionable.

As he eschews the role of rigid 'preacher' in favour of a satiric art of 'secret sapping', then, Mr Town himself comes to resemble the 'pretty preacher' described in essay number 126, who aims at 'politeness and good-breeding, takes the ladies to task in a genteel vein of raillery, and handles their modish foibles with the same air that he gallants their fans'. ${ }^{41}$ This is not to deny that The Connoisseur contains much in the way of genteel raillery against modish follies, which amounts, in its sum, to an extensive (if relatively restrained) critique of contemporary culture. Such a critique is, to a large extent, what readers would have expected from a literary periodical at this time. As Richard Squibbs has argued in a broad discussion of the whimsical periodical persona from The Spectator to the nineteenth-century American essayists, the 'reading publics' that periodicals project during this period 'locate ultimate value in renouncing the distractions of fashion and novelty in favor of the more durable pleasures of enriching character through reading, reflection, and sociable exchange'. ${ }^{42}$ Yet while Squibbs' assessment carries weight as a broad overview, in The Connoisseur specifically this whimsical, ironic method also threatens to render the renunciation of fashion and novelty largely opaque, and thus to register not an oppositional stance (as Squibbs 
argues) but, rather, an accommodation with the commercially underpinned, fashiondriven cultural scene.

In its satiric restraint, then, The Connoisseur risked unmooring itself from its Addisonian anchor. The journal's treatment of luxury - the touchstone of contemporary anxieties regarding the effects of cultural commercialism - is a key case in point here. As Jonathan Conlin notes, the 1750s was a critical decade for the eighteenth-century debates over luxury and its potentially enervating effects upon the British nation. ${ }^{43}$ In The Connoisseur, this concern about luxury is clearly evidenced in Mr Town's criticisms of the importation of foreign (specifically, French) fashions. Yet at other moments the journal's treatment of luxury is more suggestive of a gentlemanly concord with the world of fashion. Issue 74, for instance, begins with Mr Town criticising the voguish 'method of reproof' that involves comparing the present unfavourably with the past (as when, pointedly, 'the critic shakes his head at Mr. TOWN, and mentions BICKERSTAFF'), and querying the negative evaluation of the present that this entails. As he puts it, 'our unhappy metropolis is every day threatened with destruction for its degeneracy from the rigid maxims of Rome or Sparta'. Having criticised the immodest self-praise of the ancients that underpinned these impossible standards, Mr Town proceeds more predictably to expose the affectations of the modern genteel, who have begun to adopt an 'inarticulate lisp' and who have gone so far - to be fashionable - as to pretend to defects and vices that they do not possess. Yet if this faking of personal foibles and vices might seem to offer clear evidence of luxurious degeneracy, in $\mathrm{Mr}$ Town's assessment the final irony of these fashionable affectations is that 'the generality of the gay world are arrant hypocrites in their vices, and appear to be worse than they really are'. ${ }^{44}$ Such worshippers at the altar of Fashion, then, are not actually as bad as 
they seem. Given this appraisal, even the most decided affectations - such as the faked fashionable 'lisp’ - will not be judged too harshly by the whimsical Mr Town. ${ }^{45}$

While some readers of The Connoisseur may have taken this oscillating discussion of modern luxury as a subtly sophisticated satire, it also renders Mr Town a somewhat ambivalent figure in his relation to the realms of fashion and novelty (the supposed targets of the periodical-persona's whimsicality). As Bertelsen notes, along with his 'insider's knowledge of London', Mr Town also displays an 'enjoyment of the follies of the metropolis' that is 'not strictly consistent with' his self-appointed role as 'censor general' ${ }^{46}$ The possessive within the phrase 'our fashionable excesses', we might say, embraces Mr Town and his readers, as well as the beau monde itself. As his moniker quite literally declares, in the final analysis Colman and Thornton's figurehead is as much a man of the town as he is a detached spectator upon it.

How should we account for this slight but significant inflection in the positioning of polite periodical personae in the forty years between Addison and Steele and The Connoisseur? Mr Town is at least partly, I would argue, a product of changing times. In particular, The Connoisseur bears witness to significant shifts in the genteel leisure industry by the middle of the eighteenth century. Fashionable culture was now more established and visible, and expanded in its locations - a process epitomised by the major London pleasure gardens that had opened since the time of The Spectator. As The Connoisseur itself attests, high-end leisure entertainments were proliferating as never before. In a letter that employs the conceit of laying a tax or duty upon 'the fashionable amusements of the gay and polite world' (routs, drums, assemblies, and the like), one of the journal's correspondents observed that there were now upwards of 8300 such 
amusements in the town annually - a comically hyperbolic claim that nonetheless registered the extent and permeation of fashionable culture by this juncture. ${ }^{47}$ Moreover, as Mr Town also acknowledges, one undeniably major change during this period had seen women, who were 'formerly kept at home', coming out into public for the purposes of amusement and pleasure, being 'introduced to the politest routs and assemblies [...] carried to Vauxhall, Ranelagh, and other genteel places of amusement' ${ }^{48}$ In the growth and the enhanced cultural profile of this sphere of fashionable entertainment, we can see the reason for The Connoisseur's particular focus on such places of diversion about town - the spaces, that is, where the leisure pursuits of the beau monde could be most directly scrutinised.

Traditionally, the most-cited quotation concerning The Connoisseur is Johnson's curt observation, in Boswell's Life, that it 'wanted matter'. Less often noted is Boswell's defence of the journal's 'just views of the surface of life, and [...] very sprightly manner' ${ }^{49}$ Alongside Bowell's retort, it is also worth citing Catherine Talbot's early response to Johnson's own periodical publication, The Rambler; from which, Talbot declared, she would have preferred more on 'the living manners of the times $[\ldots]$ The stage, - the follies and fashions'. ${ }^{50}$ As against the more ethical focus of Johnson’s essays, it was this desire for material regarding current manners, the reigning 'follies and fashions', that would be satisfied in the pages of The Connoisseur during the mid1750s. Both the ethical lightness and the uniformity of focus of the periodical centred in the figure of Mr Town, a dedicated follower of fashion in more than a purely observational sense. Nowhere is this more apparent than in the penultimate number (essay 139), in which some attempt is made to summarise the effects, and the effectiveness, of the journal. Things get off to a bad start in the letter that opens the essay, as Mr Village expresses concern that the journal has had the unfortunate 
consequence of introducing London vogues and vices into the country, by publicising them and thereby making them available for provincial readers to mimic. As Mr Town proceeds to reflect upon his failure to 'reform the present Taste in literature', the facetious terms in which he confesses to having envisaged his success reveal once more his proximity to the very town life that has been the focus of his scrutiny as 'censor general'. Not only has he not received the freedom of the theatres for his efforts, he notes, but he has even been ignored by the proprietors of the public gardens. As he puts it in an allusion back to issue number 72, in which he had complained of the quality of the ballads sung at the gardens: 'I expected to have the priviledge [sic] of eating beef gratis every night at Vauxhall, for advising the garden-poets to put a little meaning into their songs' ${ }^{51}$ As one of the final views of their persona that Thornton and Colman present to their readers, this is, we might conclude, entirely fitting: an image of $\mathrm{Mr}$ Town himself at Vauxhall, consuming the reward for his (ineffectual) improvements to the Gardens’ entertainments.

From the start, The Connoisseur had appropriated the subjects and manner of The Spectator. Viewed positively, this comprised a process of renewal, of reprising the methods of the earlier journal for a later moment. Yet, as Colman and Thornton discovered, it was not possible simply to adopt the garb of The Spectator. In the wake of Addison and Steele themselves and in a new historical context, the Spectator's attire was not such a comfortable fit. While Addison and Steele had been able to remain partially detached from the fashionable culture of their own age, Colman and Thornton were less able to do so. As the times had changed, so must its censors: appropriating the Spectatorial model now involved re-tailoring the censor's clothing. In seeking to update the Addisonian essay, Colman and Thornton ended up adapting their model text in ways that risked rendering the censor-satirist inseparable from the follies he purported to 
critique. In his attempt to comprehend the contemporary fashionable milieu, $\mathrm{Mr}$ Town was thus drawn from a detached position of critical censor-ship to an attitude that we might instead term involved irony.

${ }^{1}$ Jason D. Solinger, Becoming the Gentleman: British Literature and the Invention of Modern Masculinity, 1660-1815 (New York: Palgrave Macmillan, 2012), chap. 3.

${ }^{2}$ Simon Dickie, Cruelty and Laughter: Forgotten Comic Literature and the Unsentimental Eighteenth Century (Chicago: University of Chicago Press, 2011), pp. 8, 139-41.

${ }^{3}$ Richard Squibbs, Urban Enlightenment and the Eighteenth-Century Periodical Essay: Transatlantic Retrospects (Basingstoke: Palgrave Macmillan, 2014), pp. 81, 87.

${ }^{4}$ Manushag N. Powell, ‘New Directions in Eighteenth-Century Periodical Studies’, Literature Compass, 8/5 (2011), 240-57 (pp. 240, 250).

${ }^{5}$ Hannah Greig, The Beau Monde: Fashionable Society in Georgian London (Oxford: Oxford University Press, 2013), pp. 3-4.

${ }^{6}$ Despite this relatively short-lived initial run, collected editions and selections from The Connoisseur continued to appear throughout the second half of the century. The journal reached its fourth London edition in 1761 (all four editions being published by Robert Baldwin), along with a Dublin edition published in 1756 by George Faulkner. Two Oxford editions appeared, from Baldwin and others, in 1767 and 1774, while, later in the century, the journal also featured in two anthologies of 'British Classics' Harrison’s (first published 1786) and Parsons' (first published 1793) - along with one selection of 'beauties': The Beauties of the Rambler, Adventurer, Connoisseur, World, and Idler (1787). A further London edition also appeared in 1795.

${ }^{7}$ Lance Bertelsen, The Nonsense Club: Literature and Popular Culture, 1749-1764 (Oxford: Clarendon Press, 1986), p. 45.

${ }^{8}$ John Brewer, The Pleasures of the Imagination: English Culture in the Eighteenth Century (New York: Farrar, Straus and Giroux, 1997), p. 92. 
${ }^{9}$ On the bellicose nature of literary culture at this time see Thomas Keymer, 'Paper Wars: Literature and/as Conflict during the Seven Years' War', in The Culture of the Seven Years' War: Empire, Identity, and the Arts in the Eighteenth-Century Atlantic World, ed. by Frans De Bruyn and Shaun Regan (Toronto: University of Toronto Press, 2014), pp. 119-46. As Manushag Powell’s broad study of eighteenth-century periodicals and authorship confirms, The Connoisseur was something of an exception to the inter-journal controversies of the period, being involved in just passing contentions with Frances Brooke’s Old Maid. See Performing Authorship in Eighteenth-Century English Periodicals (Lewisburg, PA: Bucknell University Press, 2012), pp. 161-68.

${ }^{10}$ On the reputation of Addison and his journals during this period, see Lawrence E. Klein, 'Addisonian Afterlives: Joseph Addison in Eighteenth-Century Culture', Journal for Eighteenth-Century Studies, 35 (2012), 101-18. As Klein notes, Addison's periodicals were often 'arrogated to him alone’ during these years, despite having mainly been collaborative productions (p. 103).

${ }^{11}$ As Erin Mackie argues, 'The Tatler and The Spectator register a deep ambivalence about fashion, especially their own fashionability as modish lifestyle magazines': Market à la Mode: Fashion,

Commodity, and Gender in 'The Tatler' and 'The Spectator' (Baltimore: Johns Hopkins University Press, 1997), p. 5.

${ }^{12}$ The Connoisseur, 11 (11 April 1754), 62. References to the journal give the essay number, the original date of publication, and the page number in the first collected edition: The Connoisseur, 2 vols (London, 1755-56).

${ }^{13}$ Bertelsen, Nonsense Club, p. 56.

${ }^{14}$ Connoisseur, 32 (5 September 1754), 187-88.

${ }^{15}$ Connoisseur, 36 (3 October 1754), 215; 31 (29 August 1754), 184.

${ }^{16}$ Connoisseur, 60 (20 March 1755), 358. Conversely, it might be noted, during this dialogue the tea-table is itself criticised by the card-table for fomenting scandals.

${ }^{17}$ Connoisseur, 15 (9 May 1754), 87. Horace Walpole recorded having seen just such a bet in the 'wagerbook' at White's Chocolate House, concerning the anticipated demise of the celebrity octogenarians Colley Cibber and Richard ‘Beau’ Nash. The bet, between Lord Montfort and John Bland, wagered 'twenty guineas that Nash outlives Cibber!': Horace Walpole to Richard Bentley, 31 October 1755, in The Yale Edition of Horace Walpole's Correspondence, ed. by W.S. Lewis et al, vol. 35 (London: Oxford 
University Press, 1973), p. 258. Noting that 'laying Wagers' is ‘the highest Article of modern Pleasure', Francis Coventry's novel Pompey the Little (1751) also reported the contemporary popularity of 'running Lives', i.e., of betting on which of two men would die first: The History of Pompey the Little; or, The Life and Adventures of a Lap-Dog, ed. by Nicholas Hudson (Peterborough, ONT: Broadview, 2008), p. 109.

${ }^{18}$ Connoisseur, 76 (10 July 1755), 452.

${ }^{19}$ Connoisseur, 94 (13 November 1755), 567, 570.

${ }^{20}$ Connoisseur, 24 (11 July 1754), 141-44.

${ }^{21}$ Solinger, Becoming the Gentleman, pp. 67, 72.

${ }^{22}$ Connoisseur, 2 (7 February 1754), 9.

${ }^{23}$ Connoisseur, 1 (31 January 1754), 5.

${ }^{24}$ Connoisseur, 3 (14 February 1754), 15-16.

${ }^{25}$ Connoisseur, 8 (21 March 1754), 47-48.

${ }^{26}$ Connoisseur, 139 (23 September 1756), 836.

${ }^{27}$ Connoisseur, 92 (30 October 1755), 557.

${ }^{28}$ Monthly Review, 16 (May 1757), 444.

${ }^{29}$ Thomas Keymer has written in similarly Bloomian terms of the 'anxiety of Spectatorial influence' under which Tristram Shandy endeavours to write his autobiography in serial form, in Sterne’s novel of 175967: Sterne, the Moderns, and the Novel (Oxford: Oxford University Press, 2002), p. 133. This anxiety, I would venture, was more keenly and directly felt by Colman and Thornton in their Spectatorial periodical venture.

${ }^{30}$ Terence Bowers, 'Universalizing Sociability: The Spectator, Civic Enfranchisement, and the Rule(s) of the Public Sphere', in 'The Spectator': Emerging Discourses, ed. by Donald J. Newman (Newark: University of Delaware Press, 2005), pp. 150-74 (p. 170).

${ }^{31}$ Klein, ‘Addisonian Afterlives’, pp. 107, 102.

${ }^{32}$ Connoisseur, 71 (5 June 1755), 421.

${ }^{33}$ Samuel Johnson, 'Addison', in Lives of the English Poets, ed. by George Birkbeck Hill, 3 vols (Oxford: Clarendon Press, 1905), II, 79-158 (pp. 93, 148).

${ }^{34}$ Connoisseur, 71 (5 June 1755), 421-22. 
${ }^{35}$ Jorge Luis Borges, 'Pierre Menard, Author of the Quixote' (1939), in Labyrinths: Selected Stories and Other Writings, ed. by Donald A. Yates and James E. Irby (London: Penguin, 1970), pp. 62-71.

${ }^{36}$ Connoisseur, 71 (5 June 1755), 423. Addison uses the phrase 'new or uncommon' for the quality of objects that raise a 'Pleasure in the Imagination' in The Spectator, 412 (23 June 1712): The Spectator, ed. by Donald F. Bond, 5 vols (Oxford: Clarendon Press, 1965), III, 541.

${ }^{37}$ Connoisseur, 71 (5 June 1755), 423.

${ }^{38}$ Connoisseur, 9 (28 March 1754), 51; 26 (25 July 1754), 154.

${ }^{39}$ Connoisseur, 99 (18 December 1755), 598. In the background here may be Fielding’s characterisation of the church as one of two places (the other being the theatre) that were divided between 'People of Fashion' and 'People of no Fashion', along with Lady Booby's designation of the latter as 'People one does not know', in Joseph Andrews (1742), ed. by Martin C. Battestin (Middletown, CT: Wesleyan University Press, 1967), pp. 156-57 (II.xiii).

${ }^{40}$ Connoisseur, 106 (5 February 1756), 638-39.

${ }^{41}$ Connoisseur, 126 (24 June 1756), 760.

${ }^{42}$ Richard Squibbs, ‘Civic Humorism and the Eighteenth-Century Periodical Essay’, ELH, 75 (2008), 389-413 (p. 390). See also Squibbs, Urban Enlightenment, passim.

${ }^{43}$ Jonathan Conlin, “'At the Expense of the Public”: The Sign Painters' Exhibition of 1762 and the Public Sphere’, Eighteenth-Century Studies, 36 (2002-03), 1-21 (p. 6).

${ }^{44}$ Connoisseur, 74 (26 June 1755), 439-[43].

${ }^{45}$ This is a characteristic that Goldsmith would go on to note in praising the journal's persona as a figure who 'never, for the sake of declamation, represents simple folly as absolutely criminal': Monthly Review, 16 (May 1757), 444.

${ }^{46}$ Bertelsen, Nonsense Club, p. 33. The phrase 'censor general' is taken from the journal's title page, on which Mr Town is described as 'Critic, and Censor General'.

${ }^{47}$ Connoisseur, 110 (4 March 1756), 663.

${ }^{48}$ Connoisseur, 136 (2 September 1756), 821.

${ }^{49}$ Boswell's Life of Johnson, ed. by George Birkbeck Hill, rev. and enlarged by L.F. Powell, 6 vols (Oxford: Clarendon Press, 1934), I, 420 (1 July 1763). 
${ }^{50}$ Catherine Talbot to Elizabeth Carter, 17 December 1750, in A Series of Letters between Mrs Elizabeth Carter and Miss Catherine Talbot, from the Year 1741 to 1770, ed. by Montagu Pennington, 4 vols (London: F.C. and J. Rivington, 1809), I, 371. As Peter Sabor notes, Talbot's letters to Carter about The Rambler show her 'envisaging a periodical more akin to The Spectator': 'Women Reading and Writing for The Rambler', in Women, Popular Culture, and the Eighteenth Century, ed. by Tiffany Potter (Toronto: University of Toronto Press, 2012), pp. 168-84 (p. 173).

${ }^{51}$ Connoisseur, 139 (23 September 1756), 837-38, 839. 